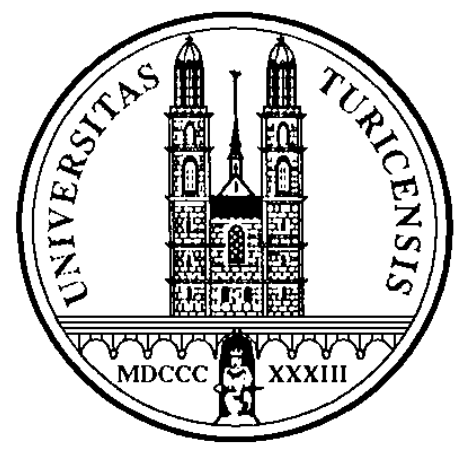

Institute for Empirical Research in Economics

University of Zurich

Working Paper Series

ISSN 1424-0459

Published in:

Journal of Population Economics, Vol. 12, 1999, 327-340

Working Paper No. 11

Do Immigrants Displace Young Native Workers:

The Austrian Experience

Rudolf Winter-Ebmer and Josef Zweimüller

June 1999 


\title{
Do Immigrants Displace Young Native Workers: The Austrian Experience
}

\author{
Rudolf Winter-Ebmer \\ University of Linz and CEPR \\ Josef Zweimüller \\ University of Zurich and CEPR
}

forthcoming in:

Journal of Population Economics (1999)

This research was supported by a grant from the Austrian National Bank (Jubiläumsfonds 4674). H. Kauer and W. Kürten provided able research assistance. Thanks to valuable comments by K. Aiginger, I. Gang, M. Landesmann, two referees and the editor K.F. Zimmermann. 


\begin{abstract}
This paper studies the effect of increased immigration in Austria on the unemployment risk of young natives. Austria experienced a dramatic rise in the share of alien workers as a result of the breakdown of the former communist regimes (especially from former Yugoslavia). We concentrate on unemployment entry of young male workers, who are supposed to compete most heavily with new immigrants. Our results indicate that the detrimental impact - if it exists at all - is only minor. This is irrespective of the analyzed proxy for competition: The share of foreign workers in an industry or in a region.
\end{abstract}

JEL: J61, J15, J64.

Keywords: Immigration, unemployment risk, native workers, 


\section{Immigration in Austria: Institutions and Recent Experience}

In recent years, immigration of labor increased in many European countries following the breakdown of former communist regimes and the resulting opening of the external borders in these countries. In the host countries, immigration is opposed by many because of the fear of detrimental labor market consequences for natives. This led countries of the European Economic Area to close external borders for immigrants, so freedom of settlement is guaranteed only within those countries.

In this paper, we study the impact of recent migration on the unemployment experience of Austrian workers. The Austrian case should be of particular interest for a variety of reasons. First of all, the major part of emigration from Eastern and South-Eastern Europe has concentrated on Austria and Germany. Between 1988 and 1991, Austrian employment rose by $6.4 \%$, and two thirds of this increase was comprised of immigration (see Table 1). At the same time, there was a slight increase in unemployment, which was more pronounced for foreign workers. As a result, the share of immigrants in the labor force almost doubled, from $5.4 \%$ in 1988 to $9.0 \%$ in 1991 . That is why we concentrate on the years 1988 and 1991 in the analysis below.

Second, the Austrian labor market is known to be influenced by strong corporatist institutions, which are characterized by highly centralized wage setting, and a strong regulation of the labor market in general. Although Austria has managed to keep unemployment rates well below the OECD-average, the rise in unemployment in the second half of the 1980s has been considerable: It is therefore suggestive to ask, whether this has a causal relation with increased immigration. 1 In the past, institutional arrangements between the central union and the central employer federation have highly regulated the influx of foreign workers, so the size of the non-Austrian work force was subject to cyclical conditions in the Austrian economy. Mainly for political reasons, this policy could not be continued at the end of the 1980s. Only in 1991, the social partners agreed upon a limitation of the number of alien workers to $9 \%$ of the total domestic work-force. So, the dramatic political changes at the end of the 1980s led to a strong labor-supply shock on the Austrian labor market.

\section{Table 1}

As far as immigration legislation is concerned, the employment of foreign labor is relatively restrictive in Austria. Work-permits for an immigrant are issued only after application of an Austrian employer. These permits are valid for a specific task within this

\footnotetext{
${ }^{1}$ See Winter-Ebmer and Zweimüller (1996) on the complementary issue of wage impacts of immigration in Austria.
} 
firm, and expire after one year. Then the immigrant can apply for a two-year extension, which allows to change jobs within a specific region. Only after three years immigrants are able to apply for a permanent work-permit. With respect to other aspects of labor-legislation, in particular social security, and pay, foreign workers are treated just like natives. There is some discrimination against foreigners in the access to unemployment benefits. Furthermore, dismissal of foreigners is easier in practice, especially if workers councils have a say. However, it is very rare that immigrants are granted Austrian citizenship.

In the next Section we briefly present some theoretical arguments as well as recent empirical evidence on the relationship between rising immigration and unemployment. Section 3 discusses data and econometric methodology. In section 4 first results using pooled cross-section are presented. In Section 5 we proceed to refine our estimates by instrumenting the foreign share variables, whereas in Section 6 , the analysis is extended using randomeffects panel regressions. Section 7 concludes.

\section{Immigration and unemployment risk}

Unemployment experience consists of the probability of losing one's job ('displacement risk') and the duration of unemployment ('job-search effectiveness'). The displacement risk applies to all employed workers whose jobs are in jeopardy due to competition from foreign workers. In Austria, this is more relevant for young workers who make the bulk of unemployment entries. Conversely, unemployment duration is much longer for older workers who happen to become unemployed. For those, the increased competition in job-search activities is more important. We will concentrate on displacement risk. This is because the measure of competition - the share of foreign workers in a certain segment of the labor market (an ndustry or a region) - becomes ambiguous in the case of job search. Workers coming from an industry or a region with many immigrant workers may surmount the difficulties in finding a job in their field by changing to other industries or regions. The impact of migration is thus intermingled with mobility aspects. In other words: job displacement risk measures first-round effects of increased immigration, whereas the latter effects may spread out over the whole economy (Chiswick, 1993).

Naive political commentators sometimes assume that incoming immigrants displace natives on a one-to-one basis. This may be the case under three conditions (Borjas, 1991, p. 81). The first is a limited number of jobs in the domestic economy, i.e. the entrance of new workers (and consumers) leaves economic growth unchanged. The second and third condition assert that natives and foreigners are perfectly substitutable and wages for foreign workers are lower than those for natives. 
The extreme opposite view would be to assume a segmented labor market (Piore, 1979), where immigrants only hold jobs that natives refuse to take. In this case no substitution of native workers would take place; on the contrary, if those jobs are complementary new employment opportunities for natives could become available in the primary sector.

Both extreme views will be unrealistic for the economy at large. In a conventional labormarket diagram a rise in immigration shifts the labor supply curve to the right. Domestic employment and wage levels would be unaffected by immigrants if market demand for these labor services were perfectly elastic at the going wage rate. Similarly there would be no change in native employment if domestic labor supply were perfectly inelastid 2 Greenwood and McDowell (1986) survey empirical elasticity estimates and conclude that "these findings are compatible with a highly inelastic supply of domestic low-skilled labor and a relatively elastic demand for such labor" (p. 1754). This would imply small negative employment impact of immigration.

Direct estimates of the impact of foreign competition usually find very small unemployment effects for the U.S. LaLonde and Topel (1991) and Altonji and Card (1991) use U.S.-Census data and compare local labor markets with differing immigration rates. (See also Simon et al (1993) or Manson et al (1985)). Freeman and Katz (1991) find a positive, though insignificant, association between the share of immigrants and the change in annual hours worked in an estimation for a panel of 428 U.S. industries.Winegarden and Khor (1991) use aggregate data on unemployment rates and undocumented aliens for U.S. states and find no detrimental impact of the latter on the former in a system of simultaneous equations. Instead, a sizable reverse effect was found: Undocumented immigrants tend to concentrate in states with favorable labor market conditions.

This possible simultaneity bias is circumvented in historical case studies of an exogenous influx of immigrants such as the "Mariel boatlift" of Cubans to Miami in 1980 (Card, 1990) or the repatriation of French citizens from Algeria in 1962 to southern France (Hunt, 1992). Both studies find only minor transitory adaptation problems on these labor markets. More severe negative impacts are found by Carrington and De Lima (1996) for Portuguese "Retornados" from Africa. The immigration to Central Europe following the fall of the "Iron Curtain" can also be interpreted as a historical natural experiment. However, this historic episode changed also trade relations leading to a vast increase of previously only very moderate imports and exports.

Further European research has concentrated on Germany and Austria. Pischke and Velling (1994) use aggregate data for German counties in the 1980s from the

\footnotetext{
2 See Johnson (1980) for a more elaborate theoretical discussion and Grossman (1982) or Borjas (1987) for empirical studies using a production function framework.
} 
"Bundesforschungsanstalt für Landeskunde und Raumordnung". Simple regression analyses reveal high employment effects of regional foreign shares. As foreigners tend to concentrate in low unemployment areas, and unemployment rates tend to be mean reverting during boom periods, there is room for spurious correlation. Taking account of mean reversion in unemployment the authors find no detrimental impact on immigration. Likewise Gang and Rivera-Batiz (1994) do not find evidence that a higher concentration of foreign-born workers are correlated with greater unemployment among native-born residents in Germany. However, unemployed Germans perceive that there is a larger presence of foreigners in their neighborhood compared to the employed (self-reported question). Contrary to this regional aspect of immigration Winkelmann and Zimmermann (1993) as well as Mühleisen and Zimmermann (1994) use the industry variation of immigration as an indicator for job competition. Using retrospective information on unemployment entry from the socio-economic panel between 1974 and 1984 model Winkelmann and Zimmermann (1993) estimate a Poisson model and find a significant impact of immigration. In a later paper Mühleisen and Zimmermann (1994) use the first six waves of the socio-economic panel and employ a dynamic multi-period probit specification. For the late eighties no detrimental impact of foreign share on the incidence of unemployment could be found. The reason for these differences might be higher wage flexibility in the later period. Furthermore, a high concentration of foreign workers in manufacturing sectors with declining employment might lead to spurious immigration effects. Hatzius (1994) uses a two-stage approach to study immigration effects in Germany. In a first stage he regresses individual unemployment on a set of region-by-period dummies and individual characteristics. Then he proceeds to use the estimated coefficients in a second regression: Differentiating between foreigners, East Germans and ethnic Germans he finds no significant effect of the presence of any of these immigrant groups on unemployment probabilities of natives. For a general assessment of European migration policies see Zimmermann (1995).

In contrast to these studies Brandel et al (1994) conclude that the recent surge of new immigrants into Austria led to a significant displacement of guest-workers of earlier generations, but also of natives: $60 \%$ of all firms in their sample with shrinking employment of natives increased the employment of foreigners in the period 1989 to 1991 . However, the latter study uses descriptive techniques rather than regression analysis. Moreover, their measure of shrinking firms does not correspond exactly to the notion of displacement, because the size of native employment can change for a variety of other reasons, like retirement and voluntary quits. 


\section{Data and Methodology}

To study the impact of immigration on the displacement risk of currently employed workers we use a sample of Austrian employees drawn from social security records. To be included in the sample a worker had to be employed either on May 31, 1988, or on May 31 1991 , or on both dates. We choose these two dates since they roughly coincide with the points of time when the recent increase in immigration started and ended, respectively.

For these individuals we have information on their working career since 1972. While all social security relevant variables (particularly labor force status and earnings) can be continuously observed, this data set has the disadvantage that ony limited information on individual characteristics is available. First, there is no information on family background. Second, the level of schooling is not directly observable and had to be approximated by the year of entry into the labor force. This gives the maximum duration of formal education. This variable seems problematic and should be cautiously interpreted. In later chapters we study also unemployment risk for immigrants already working in Austria. To minimize these problems, we restrained our samples to native workers below the age of 35 , who entered the labor market after 1972. Apart from the problem of data availability, the choice of a sample of young workers sharpens the discussion of possible displacement effects. For these effects it is critical whether immigrants are substitutes or complements to the natives. If young workers, especially unskilled ones, can be considered generally as substitutes, they should face a higher risk to be displaced.

As an indicator for displacement risk we use the probability of unemployment entry within one year (June 1988 (1991) until May 1989 (1992) for the 1988 (1991) subsample). Using this indicator should give a clear picture of first-round effects of immigration on employment stability. With at least some flexibility of wages or in the regional or industry mobility of workers, long-term employment effects will be smaller.

The empirical model can be written as follows:

$$
\begin{aligned}
& U_{i t}^{*}=S_{i t} a+X_{i t} b+e_{i t} \\
& U_{i t}=1 \text { iff } U_{i t}^{*} \geq 0 \\
& U_{i t}=0 \text { iff } U_{i t}^{*}<0
\end{aligned}
$$

$U_{i t}$ indicates whether or not individual $i$ has experienced unemployment within a year after the date of observation $\mathrm{t}(\mathrm{t}=1988,1991) . U_{i t}^{*}$ is the corresponding continuous index, which is not observable. $S_{i t}$ is a vector measuring the share of immigration in i's industry or region, 
respectively. $X_{i t}$ is a vector of individual characteristics. $a$ and $b$ are the corresponding parameters vectors to be estimated. Assuming that the error term $e_{i t}$ is standard-normally distributed, equation (1) specifies a probit-model.

The sample includes 28,775 individuals, 12,704 are observed on both baseline dates, 16,071 only once. This amounts to $41,477(=2 * 12,704+16,071)$ employment cases. Exploiting the panel-character of the sample requires at least two observations per individual, and thus leads to a loss of information. It also implies a selectivity problem by only including individuals with a more stable employment career.

We therefore adopt the following procedure. First, we run a pooled probit including all 41,477 cases and disregard possible individual effects. We present two variants of this model. We start by treating foreign shares as exogenous. Then the immigration variables are instrumented to account for a possible simultaneity bias. In the second analysis, we restrict the sample to those individuals who were observed on both dates and use panel-data methods to take advantage of individual-specific information.

\section{Results: Pooled Cross-Section Analysis}

The estimates of equation (1) are presented in Table 2. The first column refers to a probit analysis where only dummies for two industries (construction and tourism) are included. These dummies are necessary to control for the very high seasonal unemployment in these industries.The second column controls in more detail for sectoral and regional fixed effects by including 46 industry and 76 regional dummies.

Column (1) indicates a strong and highly significant impact of the immigrant share within the industry. However, including industry- and region-dummies reduces both significance and magnitude of the industry foreign share variable significantly. The likelihood ratio test in Column (2) strongly rejects the hypothesis of no sectoral and regional fixed effects, so the latter coefficient is more reliable. The marginal impact of a $1 \%$ point increase in the industry-immigrant shareleads to an increase in the risk of unemployment by about $0.17 \%$ points. Whereas the industry share has the expected positive impact on immigration on the risk of unemployment, the regional measure does not seem to have such an effect.

As far as the distinct impact of immigration at the sectoral and the regional level is concerned, the same picture remains once we redo the analysis for different subgroups. The immigrant share at the regional level turns out insignificant in all cases. At the sectoral level we find that a larger immigrant share increases the risk of joblessness only for men, but not

\footnotetext{
3 Most US studies use the regional variation in foreign share (Altonji and Card, 1991, Lalonde and Topel, 1991). German studies focus on industry variation (DeNew and Zimmermann, 1994).
} 
for women. Moreover, while no impact for white-collars and non-seasonal worker can be detected, blue-collars, seasonal workers, and - particularly strongly - foreign employees have a higher probability of unemployment entrance.

Among the control variables included in equation (1), most have the expected impact. The schooling proxy has a significantly negative impact on the risk of entering unemployment. Individuals trained in apprenticeship programmes, those who are more experienced, and have longer tenure have a significantly lower unemployment risk. Moreover, low-wage workers face a higher probability of joblessness. A more unstable employment history is an indicator for a higher unemployment risk. This is shown by the variable "number of previous jobs " and " \% unemployed days last year (two years ago)". Employees in larger firms have a higher job stability. Interestingly, the regional unemployment rate has an insignificant impact on the probability of loosing the job. This may, however, be due to the fact that drawing regional borders to determine labor market segments turns out difficult. Finally, females face a lower unemployment risk, and blue-collar workers are more concerned than white-collars.

The probit equation also includes exposure to international markets within individual i's industry as a possible determinant of unemployment risk. The fall of the Eastern borders along with a large trade creation during the years 1988 - 1991 makes it useful to distinguish trade with former communist countries in Central and Eastern Europe (CEECs) from trade with the rest of the world (RoW). These figure include trade with Poland, Hungary, the Czech Republic and Slovakia. Trade with these countries increased disproportionately during the period under consideration. The results give an unexpected picture. Industries exporting more to CEECs offered less stable jobs. On the other hand, import competition from these countries did not cause a significantly higher unemployment risk for workers in the concerned industries. The most plausible explanation for the counterintuitive CEEC-export effect may be the fact that initially exports to CEECs took place predominantely in low-tech consumer goods sectors. Moreover, exporting firms may have had to streamline production processes and cut costs to get first-mover advantages in the emerging markets. RoW-exports, on the other hand, lower the risk of unemployment, whereas RoW-imports have no significant impact on unemployment risk.

\section{Instrumented Regressions}

The results in Tables 2 and 3 treat the immigrant share as an exogenous variable. However, it is reasonable to assume that the supply of immigrants itself is caused by labor market conditions - including the risk of unemployment - in a certain sector or a certain region, respectively. If, for instance, immigration is caused by a booming region or industry, 
low unemployment risk would be associated with high foreign shares, thus the impact of immigration would be underestimated. However, most immigrants are located in old industries in decline, and in low-paid work. Reasons for this allocation are explicit recruitment effects in the past, together with network effects which facilitate the employment of newly arriving foreigners. In this case, we should expect an over-estimation of detrimental impacts of immigration.

In order to exclude a possible simultaneity bias we reran equation (1), but instrumented the foreign share within the industry and the region, respectively. The instruments used were variables describing the structure of employment in a given industry or region. This includes the share of women, the share of blue-collar workers, as well as the lagged foreign share in the corresponding labor market segment. In addition, we included the average wage among immigrants within the industry or region, which should serve as a good measure of the relative attractiveness for a foreign worker to enter such a labor market segment.

Table 4 presents the results for the foreign share coefficients, both for the whole sample and for all subgroups as in Table 3. Instrumenting foreign shares does not have a terribly strong impact on our results. As far as the regional coefficients (Column 2) are concerned all coefficients continue to show the "wrong" sign. For the perhaps more appropriate sectoral variable, the immigrant share has in general no longer a statistically significant positive impact on unemployment risk. The only exception is the sample of seasonal workers, that is workers in tourism and construction industries. The coefficient for the subsample of foreign workers is also very large, but is no longer statistically significant.

\section{Random Effects Analysis}

The previous results referred to employment cases, rather than to individuals. A large number of individuals in our sample were employed at both baseline dates. This makes it possible to redo the above analysis exploiting the longitudinal character of our sample. It has to be noted, however that the number of individuals of this pooled sample is significantly smaller, because a large number of individuals were not employed on both baseline dates. Thus, the results presented below refer to the subsample of a group with a relatively more stable working career.

In order to do that we ran a random effects probit model. Such a specification gives the following structure to the error term $e_{i t}$ in equation (1).

$$
\begin{aligned}
& e_{i t}=u_{i}+v_{i t} \\
& \text { with } \operatorname{Var}\left(u_{i}+v_{i t}\right)=\sigma_{u}^{2}+\sigma_{V}^{2}
\end{aligned}
$$




$$
\text { and rho }=\operatorname{Corr}\left(e_{i t}, e_{i s}\right)=\sigma_{u}^{2} /\left(\sigma_{u}^{2}+\sigma_{v}^{2}\right) \quad \mathrm{t}=1988, \mathrm{~s}=1991
$$

Clearly, a random effects specification requires that there is significant variation in the individual specific error term $u_{i}$. In other words, the parameter rho measuring the correlation between the error terms of the two periods has to be significant. Table 5 shows that rho is significant in all but two sub-samples (white-collar workers and foreign employees), so individual-specific effects are of importance in most regressions.

What is interesting for our purposes is whether or not the change in the estimation method has an impact on the relationship between the immigrant share and the probability of unemployment entry. Columns (1) and (2) of Table 5 show, that it does not. Just like before, the impact of immigration on the risk of joblessness is significant for seasonal workers (industry foreign share). Again, the point estimate of the sectoral foreign share for foreign workers is rather high, but barely statistically significant.

\section{Conclusions}

In this paper we have investigated the impact of immigration on the probability of unemployment entry in Austria. This can be seen as a short-run effect giving an upper limit for detrimental impacts on natives: the availability of foreign workers makes the displacement of natives possible in the first place. More long-term effects should be less severe for natives: native workers can escape immigrant competition in specific sectors or regions of the economy by moving to other industries or regions.

Our estimates concentrate on the period 1988 - 1991 when a significant influx of foreign workers took place. Our results indicate only a modest impact of immigration on the unemployment risk of native employees. However for certain subgroups particularly for seasonal workers as well as for already employed immigrants, the presence of immigrants has a quantitatively large (though not always significant) impact on the probability of unemployment. The results are robust to various specifications: whether or nor the immigrant share is instrumented to account for possible simultaneity bias; and whether or not we include individual effects exploiting the panel-design for a subsample of the data. This affects the results only quantitatively. The general picture, however, remains qualitatively the same. This corresponds to wage effects of immigration which are also found to be negligible or even positive for the Austrian case (Winter-Ebmer and Zweimüller, 1996).

It is worth noting that our results refer only to younger workers, below the age of 35 . To study displacement processes this group should be a good sample. Younger workers have less firm-specific human capital and involve only low dismissal costs like severance pay and the 
like. For the period under consideration unemployment entry and duration remained fairly constant for this group. The main feature of the rise in the unemployment rate was due to a rise in duration among older people. This can be explained by specific social and Labor laws (Winter-Ebmer, 1996). This is not to say that immigration did have no impact on the Austrian labor market. To complement the above analysis, direct job search competition among unemployed individuals has to be studied. Moreover, another possible impact of immigration may come from its impact on labor mobility of natives (Chiswick, 1993, Filer, 1992). 


\section{References}

Altonji, Joseph G. and David Card: The Effects of Immigration on the Labor Market Output of Less-skilled Natives, in: Abowd, John M. and Richard B. Freeman (eds.), Immigration, Trade, and the Labor Market, Chicago: University of Chicago Press for NBER, 1991, 201-234.

Borjas, George J.: Friends or Strangers, 1991, NY: Basic Books.

Borjas, George J.: Immigrants, Minorities, and Labor Market Competition, Industrial and Labor Relations Review 40, 1987, 382-392.

Brandel, Franz, Hofer, Helmut and Karl Pichelmann: Verdrängungsprozesse am Arbeitsmarkt, Research Memorandum No. 345, Institute for Advanced Studies, Vienna, 1994.

Card, David: The Impact of the Mariel Boatlift on the Miami Labor Market, Industrial and Labor Relations Review 43, 1990, 245-257.

Carrington, William I. and Pedro de Lima: The Impact of 1970's Repatriates from Africa on the Portuguese Labor Market, Industrial and Labor Relations Review, 49, 1996, 330347.

Chiswick, Barry R.: Review of Immigration and the Work Force by Borjas and Freeman, Journal of Economic Literature 31, 1993, 910-911.

De New, John P. and Klaus F. Zimmermann: Native Wage Impact of Foreign Labor: A Random Effects Panel Analysis, Journal of Population Economics, 1994.

Filer, Randall K.: The Effect of Immigrants Arrival on Migratory Patterns of Native Workers, in: Borjas, George J. and Richard B. Freeman (eds.), Immigration and the Work Force, Chicago: University of Chicago Press for NBER, 1992, 245-270.

Freeman, Richard B. and Lawrence H. Katz: Industrial Wage and Employment Determination in an Open Economy, in: Abowd, John M. and Richard B. Freeman (eds.), Immigration, Trade, and the Labor Market, Chicago, University of Chicago Press for NBER, 1991, 235-259.

Gang, Ira N. and Francisco L. Rivera-Batiz: Unemployment and Attitudes towards Foreigners in Germany, in: Steinmann, Gunter and Ralf Ulrich (eds.): Economic Consequences of Immigration to Germany, Berlin: Springer, 1994.

Greene, William H.: Limdep Version 6.0, User's Manual and Reference Guide, 1991, Bellport NY: Econometric Software Inc.

Greenwood, Michael I. and John M. McDowell: The Factor Market Consequences of U.S. Immigration, Journal of Economic Literature 24, 1986, 1738-1772.

Grossman, Jean: The Substitutability of Natives and Immigrants in Production, Review of Economics and Statistics 43, 1982, 245-258. 
Hatzius, Jan: The Unemployment and Earnings Effects of German Immigration, mimeo, Merton College, Oxford, 1994.

Hunt, Jennifer: The Impact of the 1962 Repatriates from Algeria on the French Labor Market, Industrial and Labor Relations Review 45, 1992, 556-572.

Johnson, George E.: The Labor Market Effects of Immigration, Industrial and Labor Relations Review 33, 1980, 331-341.

LaLonde, Robert J. and Robert H. Topel: Labor Market Adjustments to Increased Immigration, in: Abowd, John M. and Richard B. Freeman (eds.), Immigration, Trade, and the Labor Market, Chicago: University of Chicago Press for NBER, 1991, 167-200.

Manson, Donald et al.: Mexican Immigration to Southern California: Issues of Job Competition and Worker Mobility, Review of Regional Studies, 1985, 21-33.

Mühleisen, Martin and Klaus F. Zimmermann: A Panel Analysis of Job Changes and Unemployment, European Economic Review, 38, 1994,793-801.

Piore, Michael J.: Birds of Passage: Migrant Labor and Industrial Societies, 1979, Cambridge: CUP.

Pischke, Jörn-Steffen and Johannes Velling: Labor Market Effects of Foreign Employment in Germany, CEPR working paper 935, 1994.

Simon, Julian L., Stephen Moore and Richard Sullivan: The Effect of Immigration on Aggregate Native Unemployment: An Across-City Estimation, Journal of Labor Research 14, 1993, 299-316.

Veall, Michael \& Klaus F. Zimmermann: Pseudo $\mathrm{R}^{2}$ Measures for Some Commen Limited Depended Variable Models, Journal of Economic Surveys 10/3, 1006, 241-159.

Winegarden, C.R. and Lay Boon Khor: Undocumented Immigration and Unemployment of U.S. Youth and Minority Workers: Econometric Evidence, Review of Economics and Statistics, 1991, 105-112.

Winkelmann, Rainer and Klaus F. Zimmermann: Ageing, Migration and Labour Mobility, in: Johnson, Paul and Klaus F. Zimmermann (eds.): Labour Markets in an Ageing Europe, Cambridge: CUP, 1993, 255-283.

Winter-Ebmer, Rudolf and Josef Zweimüller: Immigration and the Earnings of Young Native Workers, Oxford Economic Papers, 48, 1996, 473-491.

Winter-Ebmer, Rudolf: Benefit Duration and Unemloyment Entry: Quasi-Experimental Evidence for Austria, CEPR WP 1521, 1996.

Zimmermann, Klaus F.: Tacking the European Migration Problem, Journal of Economic Perspectives 9, 1995, 45-62. 
Table 1: $\quad$ Migration and Employment in Austria

$\begin{array}{cllll} & 1988 & 1989 & 1990 & 1991 \\ \begin{array}{c}\text { Employment ('000) } \\ \begin{array}{c}\text { Unemployment rate } \\ \text { natives (\%) }\end{array}\end{array} & 5.3 & 5.0 & 5.4 & 5.8 \\ \begin{array}{c}\text { Unemployment rate } \\ \text { foreigners (\%) }\end{array} & 6.2 & 5.9 & 7.8 & 7.1 \\ \begin{array}{c}\text { Foreign share of } \\ \text { employment }(\%)\end{array} & 5.4 & 5.9 & 7.5 & 9.0 \\ & & & & 2856\end{array}$

Source: Statistisches Taschenbuch der Arbeitkammer, Vienna various years 
Table 2: Unemployment entry (Probit regressions, t-values in par.)

\begin{tabular}{|c|c|c|c|}
\hline & $\begin{array}{l}\text { without } \\
\text { dummies }\end{array}$ & $\begin{array}{r}\text { including } \\
\text { dummies }\end{array}$ & $\begin{array}{c}\text { Mean } \\
\text { (std. dev.) }\end{array}$ \\
\hline foreign share in industry & $\begin{array}{c}1.720 \\
(10.06)\end{array}$ & $\begin{array}{l}0.537 \\
(1.96)\end{array}$ & $\begin{array}{c}0.087 \\
(0.063)\end{array}$ \\
\hline foreign share in region & $\begin{array}{l}-1.334 \\
(-4.58)\end{array}$ & $\begin{array}{l}-0.417 \\
(-0.84)\end{array}$ & $\begin{array}{c}0.063 \\
(0.039)\end{array}$ \\
\hline schooling (yrs) & $\begin{array}{l}-0.024 \\
(-5.99)\end{array}$ & $\begin{array}{l}-0.027 \\
(-6.69)\end{array}$ & $\begin{array}{c}9.609 \\
(2.391)\end{array}$ \\
\hline apprenticeship $(0,1)$ & $\begin{array}{l}-0.061 \\
(-3.35)\end{array}$ & $\begin{array}{l}-0.082 \\
(-4.35)\end{array}$ & $\begin{array}{c}0.479 \\
(0.500)\end{array}$ \\
\hline experience (yrs) & $\begin{array}{c}-0.030 \\
(-12.87)\end{array}$ & $\begin{array}{c}-0.033 \\
(-13.76)\end{array}$ & $\begin{array}{c}6.757 \\
(4.173)\end{array}$ \\
\hline tenure (yrs) & $\begin{array}{c}-0.223 \\
(-25.87)\end{array}$ & $\begin{array}{c}-0.214 \\
(-24.04)\end{array}$ & $\begin{array}{c}2.264 \\
(2.798)\end{array}$ \\
\hline tenure ${ }^{2}$ & $\begin{array}{c}0.015 \\
(18.66)\end{array}$ & $\begin{array}{c}0.014 \\
(17.42)\end{array}$ & $\begin{array}{c}12.949 \\
(29.437)\end{array}$ \\
\hline previous wage in '000 ATS & $\begin{array}{l}-0.007 \\
(-4.26)\end{array}$ & $\begin{array}{l}-0.008 \\
(-4.61)\end{array}$ & $\begin{array}{l}16.434 \\
(5.939)\end{array}$ \\
\hline number of previous jobs & $\begin{array}{c}0.026 \\
(18.82)\end{array}$ & $\begin{array}{c}0.026 \\
(18.53)\end{array}$ & $\begin{array}{c}6.684 \\
(5.977)\end{array}$ \\
\hline female $(0,1)$ & $\begin{array}{l}-0.043 \\
(-2.19)\end{array}$ & $\begin{array}{l}-0.065 \\
(-3.13)\end{array}$ & $\begin{array}{c}0.345 \\
(0.475)\end{array}$ \\
\hline blue-collar worker $(0,1)$ & $\begin{array}{c}0.217 \\
(10.85)\end{array}$ & $\begin{array}{c}0.220 \\
(10.20)\end{array}$ & $\begin{array}{c}0.643 \\
(0.479)\end{array}$ \\
\hline$\%$ unemployed days last year & $\begin{array}{c}1.445 \\
(26.61)\end{array}$ & $\begin{array}{c}1.418 \\
(25.92)\end{array}$ & $\begin{array}{c}0.072 \\
(0.149)\end{array}$ \\
\hline $\begin{array}{l}\text { \% unemployed days } 2 \text { years } \\
\text { ago }\end{array}$ & $\begin{array}{l}0.403 \\
(9.32)\end{array}$ & $\begin{array}{l}0.371 \\
(8.50)\end{array}$ & $\begin{array}{c}0.087 \\
(0.178)\end{array}$ \\
\hline firm size (in '000) & $\begin{array}{l}-0.041 \\
(-3.17)\end{array}$ & $\begin{array}{l}-0.065 \\
(-4.36)\end{array}$ & $\begin{array}{c}0.974 \\
(0.673)\end{array}$ \\
\hline regional unemployment rate & $\begin{array}{l}-0.062 \\
(-0.34)\end{array}$ & $\begin{array}{l}-0.060 \\
(-0.21)\end{array}$ & $\begin{array}{c}0.057 \\
(0.042)\end{array}$ \\
\hline eastern region $(0,1)$ & $\begin{array}{l}-0.145 \\
(-5.21)\end{array}$ & - & 0.412 \\
\hline middle region $(0,1)$ & $\begin{array}{l}-0.097 \\
(-3.90)\end{array}$ & - & 0.444 \\
\hline
\end{tabular}




\begin{tabular}{|c|c|c|c|}
\hline $\begin{array}{l}\text { city size }>100,000 \& \\
<1,000,000 \\
(0,1)\end{array}$ & $\begin{array}{l}0.002 \\
(0.07)\end{array}$ & - & 0.141 \\
\hline city size > 999,999 $(0,1)$ & $\begin{array}{l}0.060 \\
(2.14)\end{array}$ & - & 0.230 \\
\hline construction sector $(0,1)$ & $\begin{array}{c}0.286 \\
(11.53)\end{array}$ & - & 0.140 \\
\hline tourism sector $(0,1)$ & $\begin{array}{l}0.131 \\
(3.77)\end{array}$ & - & 0.104 \\
\hline CEEC-export share in industry & $\begin{array}{l}1.471 \\
(2.00)\end{array}$ & $\begin{array}{l}1.056 \\
(4.49)\end{array}$ & $\begin{array}{c}0.010 \\
(0.026)\end{array}$ \\
\hline $\begin{array}{l}\text { CEEC-import share in } \\
\text { industry }\end{array}$ & $\begin{array}{l}-3.506 \\
(-3.67)\end{array}$ & $\begin{array}{l}-1.855 \\
(-1.03)\end{array}$ & $\begin{array}{c}0.005 \\
(0.010)\end{array}$ \\
\hline RoW-export share in industry & $\begin{array}{l}-0.087 \\
(-1.23)\end{array}$ & $\begin{array}{l}-3.364 \\
(-4.67)\end{array}$ & $\begin{array}{c}0.179 \\
(0.346)\end{array}$ \\
\hline RoW-import share in industry & $\begin{array}{l}-0.002 \\
(-0.06)\end{array}$ & $\begin{array}{l}-0.332 \\
(-0.92)\end{array}$ & $\begin{array}{c}0.230 \\
(0.551)\end{array}$ \\
\hline constant & $\begin{array}{l}-0.301 \\
(-4.56)\end{array}$ & $\begin{array}{l}-0.162 \\
(-1.39)\end{array}$ & \\
\hline
\end{tabular}

number of industry dummies

$\begin{array}{cc}- & 46 \\ - & 76 \\ 0.258 & 0.258 \\ 41477 & 41477 \\ -18935 & -18583 \\ 9455 & 10159\end{array}$

LRT for inclusion of industry and regional dummies $R^{2}{ }_{V Z} \|^{-1}$

0.348

704

0.369

\footnotetext{
${ }^{4}$ Quasi R ${ }^{2}$ according to Veall and Zimmermann (1996)
} 
Table 3: Unemployment entry (Probit regressions including industry and regional dummies for subgroups, $t$-values in par.)

\begin{tabular}{|c|c|c|c|c|}
\hline subgroup & $\begin{array}{c}\text { coefficient of } \\
\text { foreign share } \\
\text { in industry }\end{array}$ & $\begin{array}{c}\text { coefficient of } \\
\text { foreign share } \\
\text { in region }\end{array}$ & $N$ & $\begin{array}{c}\text { Mean of } \\
\text { dependent } \\
\text { variable }\end{array}$ \\
\hline men & $\begin{array}{l}0.845 \\
(2.47)\end{array}$ & $\begin{array}{l}0.237 \\
(0.38)\end{array}$ & 27166 & 0.272 \\
\hline women & $\begin{array}{l}0.252 \\
(0.54)\end{array}$ & $\begin{array}{l}-1.120 \\
(-1.25)\end{array}$ & 14311 & 0.231 \\
\hline blue-collar workers & $\begin{array}{l}0.934 \\
(3.27)\end{array}$ & $\begin{array}{l}-0.487 \\
(-0.76)\end{array}$ & 26688 & 0.322 \\
\hline white-collar workers & $\begin{array}{l}-0.267 \\
(-0.32)\end{array}$ & $\begin{array}{l}-0.123 \\
(-0.14)\end{array}$ & 14789 & 0.141 \\
\hline seasonal workers & $\begin{array}{l}0.819 \\
(2.38)\end{array}$ & $\begin{array}{l}-0.411 \\
(-0.40)\end{array}$ & 10564 & 0.450 \\
\hline non-seasonal workers & $\begin{array}{c}-0.218 \\
(-0.34)\end{array}$ & $\begin{array}{l}0.244 \\
(0.39)\end{array}$ & 30913 & 0.192 \\
\hline foreigners & $\begin{array}{l}2.907 \\
(2.86)\end{array}$ & $\begin{array}{l}-1.008 \\
(-0.53)\end{array}$ & 2056 & 0.340 \\
\hline
\end{tabular}


Table 4: Instrumented regressions ( $t$-values in parentheses)*

\begin{tabular}{|c|c|c|}
\hline subgroup & $\begin{array}{c}\text { coefficient of } \\
\text { foreign share } \\
\text { in industry }\end{array}$ & $\begin{array}{c}\text { coefficient of } \\
\text { foreign share } \\
\text { in region }\end{array}$ \\
\hline all & $\begin{array}{c}-0.013 \\
(0.01)\end{array}$ & $\begin{array}{l}-1.29 \\
(1.09)\end{array}$ \\
\hline men & $\begin{array}{c}0.413 \\
(0.33)\end{array}$ & $\begin{array}{r}-0.030 \\
(0.03)\end{array}$ \\
\hline women & $\begin{array}{l}-0.727 \\
(0.39)\end{array}$ & $\begin{array}{c}-2.524 \\
(1.41)\end{array}$ \\
\hline blue-collar workers & $\begin{array}{l}-0.029 \\
(0.02)\end{array}$ & $\begin{array}{c}-0.451 \\
(0.35)\end{array}$ \\
\hline white-collar workers & $\begin{array}{l}-0.251 \\
(0.12)\end{array}$ & $\begin{array}{r}-1.200 \\
(0.65)\end{array}$ \\
\hline seasonal workers & $\begin{array}{l}4.574 \\
(2.44)\end{array}$ & $\begin{array}{c}-4.818 \\
(2.15)\end{array}$ \\
\hline non-seasonal workers & $\begin{array}{l}-2.647 \\
(1.88)\end{array}$ & $\begin{array}{l}1.258 \\
(0.97)\end{array}$ \\
\hline foreigners & $\begin{array}{l}4.824 \\
(1.33)\end{array}$ & $\begin{array}{c}-2.033 \\
(0.69)\end{array}$ \\
\hline
\end{tabular}

* Instruments include lagged foreign shares, the share of women and blue-collar workers in the workforce as well as the mean wage of immigrants; all variables are on a regional as well as an industry level. All regressions include regional and industry dummies as appropriate. 
Table 5: Random effects probit estimates ( instrumented regression, $t$-values in parentheses)

\begin{tabular}{|c|c|c|c|c|c|}
\hline subgroup & $\begin{array}{c}\text { coefficient of } \\
\text { foreign share } \\
\text { in industry }\end{array}$ & $\begin{array}{c}\text { coefficient of } \\
\text { foreign share } \\
\text { in region }\end{array}$ & rho & $\begin{array}{l}\text { Mean of } \\
\text { dependet } \\
\text { variable }\end{array}$ & $N$ \\
\hline all & $\begin{array}{l}0.241 \\
(1.21)\end{array}$ & $\begin{array}{c}-0.165 \\
(0.46)\end{array}$ & $\begin{array}{l}0.138 \\
(4.53)\end{array}$ & 0.219 & 25404 \\
\hline men & $\begin{array}{l}1.423 \\
(1.46)\end{array}$ & $\begin{array}{r}-0.567 \\
(0.98)\end{array}$ & $\begin{array}{l}0.111 \\
(2.99)\end{array}$ & 0.236 & 17964 \\
\hline women & $\begin{array}{l}0.626 \\
(0.41)\end{array}$ & $\begin{array}{l}0.105 \\
(0.15)\end{array}$ & $\begin{array}{l}0.194 \\
(3.47)\end{array}$ & 0.181 & 7710 \\
\hline blue-collar workers & $\begin{array}{l}1.265 \\
(0.98)\end{array}$ & $\begin{array}{r}-0.879 \\
(1.07)\end{array}$ & $\begin{array}{l}0.135 \\
(3.66)\end{array}$ & 0.279 & 15118 \\
\hline white-collar workers & $\begin{array}{l}0.566 \\
(0.59)\end{array}$ & $\begin{array}{l}1.013 \\
(1.39)\end{array}$ & $\begin{array}{l}0.113 \\
(1.52)\end{array}$ & 0.0925 & 8040 \\
\hline seasonal workers & $\begin{array}{l}2.999 \\
(7.29)\end{array}$ & $\begin{array}{r}-1.471 \\
(1.90)\end{array}$ & $\begin{array}{l}0.166 \\
(2.80)\end{array}$ & 0.397 & 4554 \\
\hline non-seasonal workers & $\begin{array}{l}-0.001 \\
(0.07)\end{array}$ & $\begin{array}{l}0.817 \\
(1.87)\end{array}$ & $\begin{array}{l}0.127 \\
(3.11)\end{array}$ & 0.146 & 18120 \\
\hline foreigners & $\begin{array}{l}2.690 \\
(1.69)\end{array}$ & $\begin{array}{c}-1.341 \\
(1.34)\end{array}$ & $\begin{array}{l}0.034 \\
(0.28)\end{array}$ & 0.339 & 2056 \\
\hline
\end{tabular}

* Instruments include lagged foreign shares, the share of women and blue-collar workers in the workforce as well as the mean wage of immigrants; all variables are on a regional as well as an industry level. Rho=corr $\left(e_{i t}, e_{i s}\right)$. 